\title{
The Effect of a Training and Nutritional Program to Address the Male Gynecomastia Phenomenon
}

\author{
Ali Bedaiwi Tapoor, Ammar Muthanna Jameel, Mushtaq Abed Alredha Mashi* \\ College of Physical Education and Sports Science, University of Al-Qadisiyah, Iraq
}

Received September 23, 2020; Revised December 24, 2020; Accepted January 20, 2021

\section{Cite This Paper in the following Citation Styles}

(a): [1] Ali Bedaiwi Tapoor, Ammar Muthanna Jameel, Mushtaq Abed Alredha Mashi , "The Effect of a Training and Nutritional Program to Address the Male Gynecomastia Phenomenon," International Journal of Human Movement and Sports Sciences, Vol. 9, No. 1, pp. 34 - 40, 2021. DOI: 10.13189/saj.2021.090105.

(b): Ali Bedaiwi Tapoor, Ammar Muthanna Jameel, Mushtaq Abed Alredha Mashi (2021). The Effect of a Training and Nutritional Program to Address the Male Gynecomastia Phenomenon. International Journal of Human Movement and Sports Sciences, 9(1), 34 - 40. DOI: 10.13189/saj.2021.090105.

Copyright $@ 2021$ by authors, all rights reserved. Authors agree that this article remains permanently open access under the terms of the Creative Commons Attribution License 4.0 International License

\begin{abstract}
Some of the main problems facing sportsmen, and males in general, are obesity and the accumulation of unwanted fat. Gynecomastia is the phenomenon of a body deformity in males that occurs in the chest area and causes a lot of embarrassment. It is quite uncomfortable for sportsmen and males. They experience embarrassment and dissatisfaction, making them dress in such a way that may hide their weight or gynecomastia. The importance of this research lies in developing a general suggested rehabilitative program (training and diet) by trainers and experts in the field of training and bodybuilding. This program is developed to: address the phenomenon of gynecomastia, burning accumulated fat in the chest area, raising testosterone level, and lowering (progesterone and estrogen) hormone levels in participants. The research problem is explored through observing some males with noticeable bloated or flabby chest appearance. They are examined to check the amount of accumulated fat in their bodies -using calipers- and examine the chest glands by feeling them to detect the texture of this gland. The results are presented to doctors specialized in this field, showing that they suffer from a form of sagging. This condition occurs due to three reasons: a genetic glandular disease, a difference between the proportions of male and female hormones, or the accumulation of fats as a result of a diet containing fats, carbohydrates, and sugars which the body keeps in the form of fats in the chest area. This phenomenon is called gynecomastia. The research community consists of students from the College of Physical Education and Sport Sciences - University of Qadisiyah for the academic year 2018-2019. The sample
\end{abstract}

consists of (10) students divided into two groups (experimental and control) - (5) students per group. The researchers check the homogeneity and equivalence of the research sample in the studied variables. All field procedures have been appropriately done, from measurements to obtain the necessary data, to conducting the appropriate statistics and classifying them in the form of tables, analyzing and discussing them, and coming up with some conclusions and recommendations.

Keywords Proposed Rehabilitative Program (Training and Diet), Treating Gynecomastia

\section{Introduction}

Being attentive to the fit physical appearance has become one of the basic requirements in societies in general and in the sports community in particular. Every athlete must have an ideal figure without any fats that increase the burden while performing exercises and participating in competitions. We can notice that a fit physique greatly impacts the psychological state and boosts self-confidence.

Based on many studies conducted worldwide, we find that athletes with a fit body reach high levels of athletic achievement and achieve their goals faster than others. The male community always seeks a fit, athletic, and healthy body and stays away from the appearance of excess fat and obesity that affects their overall appearance 
and thus affects their social relationships in general and with women in particular.

Some of the main problems facing sportsmen, and males in general, are obesity and the accumulation of unwanted fat. Gynecomastia is the phenomenon of a body deformity in males that occurs in the chest area and causes a lot of embarrassment. This condition is quite uncomfortable for sportsmen and males, where they experience embarrassment and dissatisfaction that makes them dress in a certain type of way that they do not like to hide their weight and gynecomastia. This condition affects the mental health of males who suffer from it especially when dealing with society. ${ }^{1}$

The relevance of this research is in proposing a general rehabilitative program (training and diet) by trainers and workers in the field of training and bodybuilding, in addition to the central and subsidiary unions in the governorates of Iraq. This program was developed to: address the phenomenon of gynecomastia, burn accumulated fat in the chest area, raise testosterone level, and lower (progesterone and estrogen) hormone levels in participants.

\section{Research Problematic}

Societies and their nature differ in all parts of the world, and the outer appearance of males in these societies may differ according to their way of life, their beliefs, and their cultural heritage. In Arab societies, males have a certain type of distinction in terms of religion and society; they are viewed as the father and man of the house who works and toils for the sake of his family and protects, defends, and maintains his home and family. Their purpose is also affiliated with national security, by fighting against everyone who dares to attack their country. All of these things require firmness and strength that can be seen through the external masculine appearance in every detail of a man's body. An observation of some males with noticeable bloated or flabby chest appearance was done. These individuals were examined to check the amount of accumulated fat in their bodies using calipers and examine the chest glands by feeling them to detect the texture of this gland. The results presented to doctors who specialize in this field showed that they suffer from a form of sagging. This condition occurs due to three reasons: a genetic glandular disease, a difference between the proportions of male and female hormones, or the accumulation of fats as a result of a diet containing fats, carbohydrates, and sugars which the body keeps in the form of fats in the chest area. This phenomenon with all its three reasons is called gynecomastia.

\section{The Purpose of the STUDY}

To prepare a proposed rehabilitation program (training and diet) to treat gynecomastia and burn accumulated fat in the chest area (gynecomastia). The aim is to also identify the effect of this program in raising and lowering the levels of the hormones: testosterone, progesterone, and estrogen; and what may result from this whether positively or negatively in terms of development and variations that will occur to both groups (experimental and control) and to check what works better for them.

\section{Research Methodology and Field Procedures}

\section{Research Methodology}

The researchers used the experimental approach and equivalent groups method because it meets the needs of the research: accurate results.

\section{Research community and sample}

The research community included (183) first stage students of the College of Physical Education and Sport Sciences at the University of Qadisiyah, for the academic year (2018-2019). The research sample was deliberately chosen: (10) students who suffer from gynecomastia representing the proportion (5.464\%) of the research community. Homogeneity and equivalence were achieved between the two groups in variables (height, weight, age).

Table 1. Shows the homogeneity of the two groups

\begin{tabular}{|c|c|c|c|c|}
\hline Variables & Units & Mean & SD & $\begin{array}{c}\text { Coefficient of } \\
\text { variation (Cv) }\end{array}$ \\
\hline Length & $\mathrm{Cm}$ & $\mathbf{1 6 9 . 1 1 8}$ & 4.133 & $\mathbf{2 . 4 4 3} \%$ \\
\hline weight & $\mathrm{Kg}$ & 75.792 & 5.993 & $\mathbf{7 . 9 0 7} \%$ \\
\hline Age & Year & 19.024 & 0.896 & $\mathbf{4 . 7 0 9} \%$ \\
\hline
\end{tabular}

As shown in Table (1) The $\mathrm{Cv}$ values are less than (30\%). This proves the homogeneity of the sample in one group, "the more the coefficient of variation is near (1\%) the more homogeneous the sample is, and if the Cvsurpassed (30\%) then the sample is non-homogeneous.

Table 2. Shows the equivalence of the respondents

\begin{tabular}{|c|c|c|c|c|c|c|c|}
\hline \multirow{2}{*}{ S } & \multirow{2}{*}{ Variables } & \multicolumn{2}{|c|}{ Experimental group } & \multicolumn{2}{|c|}{ Control group } & \multirow{2}{*}{$\begin{array}{l}\text { Calculated value of } \\
\text { (t) }\end{array}$} & \multirow{2}{*}{$\begin{array}{c}\text { Indication of } \\
\text { variation }\end{array}$} \\
\hline & & Mean & $\mathrm{SD}$ & Mean & SD & & \\
\hline 1 & Length & 168.261 & 3.117 & 169.961 & 4.317 & 1.093 & No sig. \\
\hline 2 & weight & 74.862 & 6.913 & 75.307 & 5.033 & 0.994 & No sig. \\
\hline 3 & Age & 19.011 & 1.438 & 19.003 & 1.015 & 0.481 & No sig. \\
\hline
\end{tabular}

* Table (T) value at the level of significance $(0.05)$ and freedom degree $(8)=1.860$ 


\section{Means, Tools and Devices Used in the Research}

- Arabic sources and references.

- Observation and experimentation.

- Testing and Measurement

- Personal interview

- Data collection form.

- Data dump form.

- Tape measure (centimeters, linen).

- Electronic medical scale to measure weight.

- Calipers for measuring the thickness of the skin folds (the accumulated fat).

- Blood tubes.

- Medical syringes to draw blood, cooler box, centrifuge to separate blood components

- Computer (type DELL) and electronic calculator (SONY).

- Camera.

- Multi gym, flat anesthesia, upper anesthesia, lower anesthetic, iron bar, iron weights, and weights.

- Sports watch to measure work time and rest.

\section{Field research procedures}

The pilot study

The researchers and the assistant work team conducted a pilot study on a sample consisting of (5) members of the research community. The experiment took place on Sunday, 10/21/2018 at 9:00 am in the physiology lab of the Faculty of Physical Education and Sports Science University of Qadisiyah. The aim of the study was the following: ${ }^{3}$

- Figuring the level of students' understanding of the elements of the diet training program.

- Ensuring the validity of the tools and devices that will be used in the main experiment.

- Identifying the difficulties and problems that researchers may encounter while training, and using food and measurements to resolve them.

- Knowing the number of auxiliary staff needed by the research when taking measurements, as well as training them on the registration method.

- Knowing the time spent on taking the measurements.

\section{Pretests}

On October 25, 2018, the researchers conducted pretests of the variables on the studied research sample in the two groups (experimental and control), where the researchers took into account the fixation of conditions on the research sample in the posttests. They measured: ${ }^{4}$

-Measuring the percentage of fat accumulated in the chest area and measuring the hormone variables (testosterone, estrogen, and progesterone): The thickness of the saggy skin in the chest area was measured by a caliper to know the percentage of fat accumulated in the chest area.

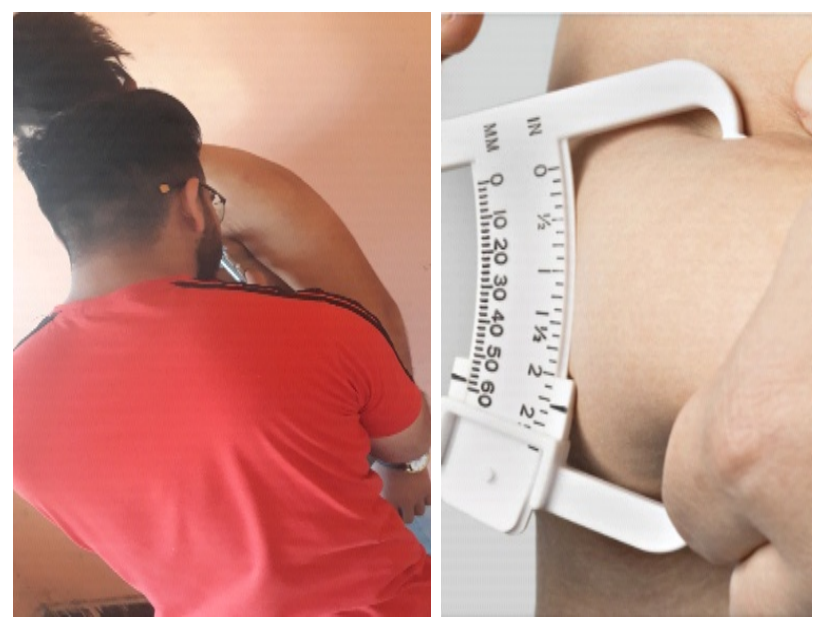

Figure 1. Shows a method for measuring skin folds in the chest area with a caliper

\section{Drawing blood samples ${ }^{5}$}

The blood sample was drawn from the students (5 cc) at the time of rest and without effort. Samples were taken from the venous blood of the upper arm region. Blood samples were placed in the blood-saving tubes which are standard tubes numbered according to the students' sequence (each number is appointed to a student) and then transferred to the laboratory to be separated by centrifugation to extract the serum (blood plasma) from each sample with the help of a specialist. They are then placed after separation in tubes marked with the student number and kept in the refrigeration box to be transferred to the laboratory for analysis (Sikma laboratory for pathological analyzes in Al-Qadisiyah Governorate). The percentage of the concentration of testosterone, progesterone, and estrogen in the blood is then known, and the results will be extracted on October 25, 2018.

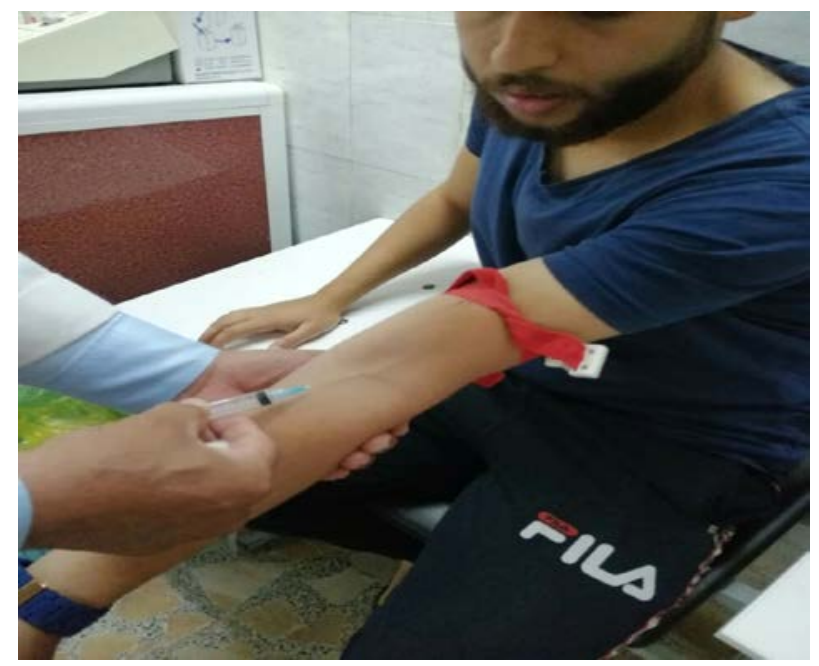

Figure 2. Shows the method of drawing blood from a student (research sample) 


\section{The main experience}

After the researchers, with the assistance of the auxiliary team, conducted the pilot experiment and did the pretests on the variables of the research sample, the main experiment included:

\section{The exercises in a single training unit that range from (5-6).}

The researchers trained the research sample with three weekly training units, whether the (experimental) group that works according to the proposed qualification program (training and diet) or the (control) group that works according to what it takes from practical lessons of its annual curriculum in the first course of all sports.

The period of these exercises: (24) units, by (3) units per week and for (8) weeks.

Duration of the unit: (90) minutes.

Training days (Sunday - Tuesday - Thursday).

- The diet plan of the proposed rehabilitation program is given based on scientific principles and its purpose is to raise the testosterone ratio of the (experimental) group along with training according to the proposed exercises.

- The endurance of each student was measured separately and he was dealt with accordingly.

- The intensity ranged between (75\% - 100\%) according to the ripple method, with repetitions and breaks between them according to the intensity levels and according to the scientific foundations of the training.

This proposed rehabilitative program (training and diet) was developed after personal interviews with experts and specialists in the field of sports training and sports diet and asking for their opinions on the importance of the used exercises in terms of their significance in raising testosterone levels and burning accumulated fat in the chest area in particular and the areas of the body in general. They were also asked about the diet plan that will be given to the research sample. The researchers then selected the best exercises that help achieve the goal and also the food used in the program and that was agreed upon by experts and specialists. Reps and intensity levels and groups and breaks were also set. ${ }^{6}$

\section{Suggested qualification program (training)}

The proposed rehabilitation program (training) was conducted on the research sample from Sunday, October 28, 2018, until December 20, 2018, through the three training units given pee week. These units included weightlifting exercises that were distributed. The training time was at 10:00 a.m. in each training unit, and the training period was from 1:00 a.m. to 1:00 p.m. All exercises begin after warm-ups and Swedish exercises, where the training units were arranged and distributed on weekdays.

\section{Suggested qualification program (diet)}

The proposed rehabilitation program (diet) was carried out on Sunday, October 28, 2018, until December 20, 2018, through which meals containing vitamin-rich food were distributed to get rid of fats and raise the levels of testosterone hormone. The food program included the following meals on Exercise days: ${ }^{7}$

\section{Breakfast}

- $\quad$ (3) Boiled egg whites + a cup of skimmed milk + walnut + toast loaf +2 tablespoons oats.

These nutrients are full of vitamins, fibers and proteins essential for burning fats, raising the hormone level, and building muscle tissues.

2. Lunch

- $\quad$ Boiled chicken breast + vegetable salad + four tablespoons boiled rice + a cup of lemon juice. The boiled chicken breast is fat-free and contains a good amount of fibers and proteins necessary for building muscles. The vegetable salad contains a great amount of vitamin $\mathrm{A}$, which promotes the stimulation of testosterone. lemon juice is rich in vitamin $\mathrm{C}$ ), which promotes tissue building and helps burn fat because it contains acidic compounds.

\section{Dinner meal}

- Grilled liver meat pieces + vegetable salad + cup of carrot juice + banana.

Where the liver contains a high amount of vitamin ( $\mathrm{K}$ and $\mathrm{D}$ ), where vitamin $(\mathrm{K})$ engages in the reactions of oxidation, reduction, and phosphorylation in burning fat. As for vitamin (D), it is necessary form muscle development and prevent atrophy. Carrot juice and leafy vegetable salads also contain a high amount of vitamin (A) which raises the level of testosterone. ${ }^{8}$

\section{Post-test}

On Sunday, December 23, 2018 at 9:00 a.m., the researchers and the team in the physiology lab at the College of Physical Education and Sports Science-University of Qadisiyah, did the posttests under the same conditions of the pretests.

\section{Statistical means}

The researchers used version (22) of the software package for statistical analysis(SPSS).

\section{Results}

In table (3), the results show the significance of the variations after comparing the calculated value of $(t)$ with 
its tabular value. The value of $\mathrm{t}$ was greater than the tabular value at the level of significance (0.05) and freedom degree (4) for the benefit of posttests in this group. Its scale of impact was (Big) in all studied hormones, which indicates that the results of the proposed rehabilitation program (training and diet) have a positive effect in raising the level of the hormone testosterone and the decrease in the level of estrogen and progesterone. By that, the purpose of the study is achieved. ${ }^{9}$

In table (4), the results show the significance of the variations after comparing the calculated value of (t) with its tabular value. The value of $t$ was greater than the tabular value at the level of significance $(0.05)$ and freedom degree (4) for the benefit of posttests in this group. Its scale of impact was (Big) in all studied hormones, which indicates that the results of the proposed rehabilitation program (training and diet) have a positive effect on raising the level of the hormone testosterone and the decrease in the level of estrogen and progesterone. By that, the purpose of the study is achieved. ${ }^{10}$

In Table (5), the results show the significance of the variations in the posttests between the two groups (experimental and control). After comparing the calculated value of (t) between them with the tabular value. The value of $t$ was greater than the tabular value of (1.860) at the level of significance (0.05) and degree of freedom (8) for the benefit of the experimental group in the post-tests. Its scale of impact was (Big) in all studied hormones, which indicates that the results of the proposed rehabilitation program (training and diet) have a positive effect on raising the level of the hormone testosterone and the decrease in the level of estrogen and progesterone in favor of the posttest so $f$ the experimental group. By that, the purpose of the study is achieved.

Table 3. Shows the mean, the standard deviations, and the calculated value (t) of the pre- and posttests of the (experimental) group of the research variables (hormones)

\begin{tabular}{|c|c|c|c|c|c|c|c|c|c|}
\hline \multirow{2}{*}{ Hormones } & \multirow{2}{*}{ Units } & \multicolumn{2}{|c|}{ Pretest } & \multicolumn{2}{|c|}{ Posttest } & \multirow{2}{*}{$\begin{array}{l}\text { Calculated } \\
\text { value of(t) }\end{array}$} & \multirow{2}{*}{$\begin{array}{c}\text { Indication of } \\
\text { variation }\end{array}$} & \multirow{2}{*}{$\begin{array}{c}\text { Scale of } \\
\text { impact }\end{array}$} & \multirow{2}{*}{$\begin{array}{c}\text { Impact } \\
\text { indication }\end{array}$} \\
\hline & & Mean & SD & Mean & SD & & & & \\
\hline Testosterone & $\begin{array}{c}\mathrm{Ng} / \mathrm{ml} \\
\text { men }\end{array}$ & 2.240 & 0.439 & 2.800 & 0.316 & 4.346 & Sig. & 0.908 & Big \\
\hline Estradiol & $\begin{array}{l}\text { Pg / ml } \\
\text { men }\end{array}$ & 13.80 & 0.836 & 11.40 & 0.547 & 9.798 & Sig. & 0.979 & Big \\
\hline Progesterone & $\begin{array}{l}\mathrm{Ng} / \mathrm{ml} \\
\text { men }\end{array}$ & 0.520 & 0.083 & 0.320 & 0.084 & 2.333 & Sig. & 0.759 & Big \\
\hline
\end{tabular}

* Table (t) value at the level of significance $(0.05)$ and degree of freedom $(4)=(2.132)$

Table 4. Shows the mean, the standard deviations, and the calculated value (t) between the pre and posttests of the two (control) groups in the research variables (hormones)

\begin{tabular}{|c|c|c|c|c|c|c|c|c|c|}
\hline \multirow{2}{*}{ Hormones } & \multirow{2}{*}{ Units } & \multicolumn{2}{|c|}{ Pretest } & \multicolumn{2}{|c|}{ Posttest } & \multirow{2}{*}{$\begin{array}{l}\text { Calculated } \\
\text { value of(t) }\end{array}$} & \multirow{2}{*}{$\begin{array}{l}\text { Indication of } \\
\text { variation }\end{array}$} & \multirow{2}{*}{$\begin{array}{c}\text { Scale of } \\
\text { impact }\end{array}$} & \multirow{2}{*}{$\begin{array}{c}\text { Impact } \\
\text { indication }\end{array}$} \\
\hline & & Mean & SD & Mean & SD & & & & \\
\hline Testosterone & $\begin{array}{c}\mathrm{Ng} / \mathrm{ml} \\
\text { men }\end{array}$ & 2.311 & 0.519 & 2.544 & 0.385 & 2.186 & Sig. & 0.737 & Big \\
\hline Estradiol & $\begin{array}{c}\mathrm{Pg} / \mathrm{ml} \\
\text { men }\end{array}$ & 13.95 & 0.938 & 12.892 & 0.597 & 2.005 & No sig. & 0.707 & Big \\
\hline Progesterone & $\begin{array}{c}\mathrm{Ng} / \mathrm{ml} \\
\text { men }\end{array}$ & 0.530 & 0.121 & 0.379 & 0.105 & 2.208 & Sig. & 0.741 & Big \\
\hline
\end{tabular}

* Table ( $\mathrm{t}$ ) value at the level of significance $(0.05)$ and degree of freedom $(4)=(2.132)$

Table 5. Shows the mean, the standard deviations, and the calculated value ( $\mathrm{t}$ ) of the post measurements between the two groups (experimental and control) in the research variables (hormones)

\begin{tabular}{|c|c|c|c|c|c|c|c|c|c|}
\hline \multirow{2}{*}{ Hormones } & \multirow{2}{*}{ Units } & \multicolumn{2}{|c|}{$\begin{array}{l}\text { Experimental } \\
\text { group }\end{array}$} & \multicolumn{2}{|c|}{ Control group } & \multirow{2}{*}{$\begin{array}{l}\text { Calculated } \\
\text { value of(t) }\end{array}$} & \multirow{2}{*}{$\begin{array}{l}\text { Indication of } \\
\text { variation }\end{array}$} & \multirow{2}{*}{$\begin{array}{c}\text { Scale of } \\
\text { impact }\end{array}$} & \multirow{2}{*}{$\begin{array}{c}\text { Impact } \\
\text { indication }\end{array}$} \\
\hline & & Mean & SD & Mean & SD & & & & \\
\hline Testosterone & $\begin{array}{c}\mathrm{Ng} / \mathrm{ml} \\
\text { men }\end{array}$ & 2.800 & 0.316 & 2.544 & 0.385 & 4.047 & Sig. & 0.819 & Big \\
\hline Estradiol & $\begin{array}{c}\mathrm{Pg} / \mathrm{ml} \\
\text { men }\end{array}$ & 11.40 & 0.547 & 12.892 & 0.597 & 3.559 & Sig. & 0.782 & Big \\
\hline Progesterone & $\begin{array}{c}\mathrm{Ng} / \mathrm{ml} \\
\text { men }\end{array}$ & 0.320 & 0.084 & 0.379 & 0.105 & 1.944 & Sig. & 0.566 & Big \\
\hline
\end{tabular}

* Table $(\mathrm{T})$ value at the level of significance $(0.05)$ and degree of freedom $(8)=1.860$ 
Table 6. Shows the mean, the standard deviations, and the calculated value of (t) between the pre and post-tests of the two groups (experimental and control) in (the percentage of fats)

\begin{tabular}{|c|c|c|c|c|c|c|c|c|c|c|}
\hline \multirow{2}{*}{ Variable } & \multirow{2}{*}{ Units } & \multirow{2}{*}{ Group } & \multicolumn{2}{|c|}{ Pretest } & \multicolumn{2}{|c|}{ Posttest } & \multirow{2}{*}{$\begin{array}{l}\text { Calculated } \\
\text { value of(t) }\end{array}$} & \multirow{2}{*}{$\begin{array}{l}\text { Indication } \\
\text { of variation }\end{array}$} & \multirow{2}{*}{$\begin{array}{c}\text { Scale } \\
\text { of } \\
\text { impact }\end{array}$} & \multirow{2}{*}{$\begin{array}{c}\text { Impact } \\
\text { indication }\end{array}$} \\
\hline & & & Mean & $\mathrm{SD}$ & Mean & SD & & & & \\
\hline \multirow{2}{*}{ Fat ratio } & \multirow{2}{*}{$\mathrm{Mm}$} & Experimental & 2.800 & 0.324 & 2.300 & 0.308 & 9.129 & Sig. & 0.976 & Big \\
\hline & & Control & 2.839 & 0.469 & 2.658 & 0.399 & 2.107 & No sig. & 0.725 & Big \\
\hline
\end{tabular}

The value of $(\mathrm{t})$ at the significance level $(0.05)$ and the degree of freedom $(4)=2.132$

Table 7. Shows the mean, the standard deviations, and the calculated value (t) of the post measurements between the two groups (experimental and control) in a variable (percentage of fat)

\begin{tabular}{|c|c|c|c|c|c|c|c|c|}
\hline \multirow{2}{*}{ Variable } & \multicolumn{2}{|c|}{ Experimental group } & \multicolumn{2}{|c|}{ Control group } & \multirow{2}{*}{$\begin{array}{l}\text { Calculated } \\
\text { value of(t) }\end{array}$} & \multirow{2}{*}{$\begin{array}{c}\text { Indication of } \\
\text { variation }\end{array}$} & \multirow{2}{*}{$\begin{array}{l}\text { Scale of } \\
\text { impact }\end{array}$} & \multirow{2}{*}{$\begin{array}{c}\text { Impact } \\
\text { indication }\end{array}$} \\
\hline & Mean & $\mathrm{SD}$ & Mean & $\mathrm{SD}$ & & & & \\
\hline Fat ratio & 2.300 & 0.308 & 2.658 & 0.399 & 4.088 & Sig. & 0.822 & Big. \\
\hline
\end{tabular}

* The value of $(\mathrm{T})$ at the level of significance $(0.05)$ and degree of freedom $(8)=1.860$

In Table (6), the results showed the significance of the differences between the pre- and posttests of the two groups (experimental and control). After comparing the calculated value of $(\mathrm{t})$ between them with its tabular value, the calculated value of $(\mathrm{t})$ was greater than the tabular value of (2.132) at the level of significance (0.05) and degree of freedom (4) in favor of the experimental group in the post-tests. Its scale of impact was (Big) in the variable (fat ratio). This indicates that the results of the proposed rehabilitation program (training and diet) have a positive impact on the decrease of this variable. The differences were insignificant for the control group, but there is a decrease in favor of the post-tests, yet, it did not appear statistically, but appeared through the size of the effect (large), which indicates that the activities of a practical nature reduce the percentage of body fat, but not like the experimental group that showed an effect on the decrease of level of accumulated Fat in the chest area, and this fulfills the purpose of the study.

In Table (7), the results showed the significance of the variations for the post measurements between the two groups (experimental and control). After comparing the calculated value of $(\mathrm{t})$ between them with its tabular value, the calculated value of $(\mathrm{t})$ was greater than the tabular value of (1.860) at the level of significance $(0.05)$ and the degree of freedom (8) in favor of the experimental group. Its scale of impact was (Big) in the variable (fat ratio). This indicates that the results of the proposed rehabilitation program (training and diet) have a positive impact on the decrease of this variable, and on the decrease of level of accumulated Fat in the chest area, and this fulfills the purpose of the study.

\section{Discussing the Results}

Based on the results obtained from the pre and posttests, the post measurements of all hormones of both groups (experimental, and control) showed progress in the increase in testosterone level and the decrease in both progesterone and estrogen hormone levels. The level of testosterone is inversely proportional to the level of progesterone and estrogen hormones i.e. the higher the level of testosterone in the body is, the lower the percentage of estrogen and progesterone becomes .These levels are responsible for the enlargement and swelling of the mammary glands and the accumulation of fat in the chest area. This increase in testosterone levels is due to the proposed rehabilitation program (training and diet) for the experimental group. It stimulated the increase in the level of testosterone and the decrease in the levels of progesterone and estrogen hormones and accumulated fats as well. ${ }^{11}$

"The use of exercises, of a nature that issimilar to the general form of the specialized exercises, leads to better results in gaining strength". ${ }^{12}$

"Systematic training leads to an increase in the efficiency of the muscular system, and this is directly reflected through muscular endurance-whether kinetic or stationary". ${ }^{13}$

This indicates that the proposed rehabilitation program (training and diet) has a positive impact on increasing the level of testosterone and decreasing the levels of progesterone and estrogen along with a decrease in the level of accumulated fat in the chest area. The diet training program led to an increase in the size of muscle fibers and elimination of sagging in targeted areas, in addition to tightening chest muscles giving it the perfect fit look.

The results of the post measurements of hormones and fats for the research sample in the two groups in tables $(5,7)$ showed the differences between the groups in favor of the experimental group in all the variables, in addition to the big scale of impact between these two groups. The researchers attribute this to the nature of the exercises and the energy and food used to burn calories. All of that reduced the percentage of fats through warming-ups and the exercises used, regularly eating healthy food, as well as physical exercises that are based on scientific 
foundations according to intensity, repetition, etc.

The food consisted of a lot of fruits that have a great role in maintaining the regulation of fat burning and helps oxidize food in the body. The devices used helped in monitoring food and the calories loss, which consequently helped in figuring out the type of food and the exercises used to balance the number of calories intake and burn, without any problems that may arise after the deficit in these calories. "Metabolism after physical activity depends on the nature of the exercise (intensity) and the period of the performance (size)" . ${ }^{14 " E x p e r t s ~ s t r e s s ~ t h a t ~ i t ~}$ is much easier to reduce the amount of calories when eating compared to burning them by exercise" . ${ }^{15}$

As for the control group, there was a slight increase in testosterone, a decrease in the hormone (progesterone, and estrogen), and a decrease in the percentage of fats, but not as significant as the variations in the experimental group. This may be a result of them being students and their ways of burning calories are somewhat different in terms of how they perform walking exercises and other sports, especially practical games taught in college, and their participation in games such as football and others whether inside or outside of the university and any other type of work. These practices have a positive impact on the result of these variables, i.e. "After completing the physical activity, the rate of metabolism increases for several hours and calories continue to be burnt quickly " and" The used training method impacts the percentage of fats in the body ". 16

\section{Conclusions}

Through the presentation, analysis, and discussion of data, researchers reached the following conclusions:

1. The proposed rehabilitation program (training and diet) increased the level of testosterone, decreased the levels of progesterone and estrogen hormones, and significantly reduced the percentage of body and chest fats.

2. The physical changes to the shape of the chest were positively reflected in the fit appearance and raised the self-confidence of the participants.

3. The proposed rehabilitation program (training and diet) resulted in a better chest form, getting rid of gynecomastia, and gaining a muscular appearance in the chest.

\section{REFERENCES}

[1] Abu El-Ella Ahmed and Mohamed Hassan Allawi:
Physiology of Athletic Training, Cairo, Dar Al-Fikr Al-Arabi, 1985.

[2] Abu El-Ella Ahmed Abdel-Fattah and Ahmed Nasr El-Din: Physiology of Fitness, Cairo, Dar Al-Fikr Al-Arabi, 1993.

[3] Abu El-Ella Ahmed Abdel-Fattah: Athletic Training Physiological Foundations, Dar Al-Fikr Al-Arabi, Nasr City, 1997.

[4] Abu El-Ella Abdel-Fattah: Physiology and Training in Sports, Arab House of Thought, Cairo, Ed. 1, 2003.

[5] Saad Al-Din Muhammad Al-Makkawi: Endocrine Physiology and Hormones, Al-Maaref Establishment, 1st edition, 2000.

[6] Jamil Qasim Muhammad Al-Badri, Ahmad Khamis Radi Al-Sudani: The International Handball Encyclopedia, 1st edition, Al-Safa Foundation, Publications, Beirut, 2011.

[7] Abdullah Mahmoud Al-Zuhairi Al-Noun: Nutrition of Man, Dar Al-Kutub for Printing and Publishing, University of Mosul, 1992.

[8] Abdul Majeed Ibrahim Marwan: Examination and Measurement in Physical Education, Amman, Dar Al-Fikr Al-Arabi for Printing and Publishing, 1999.

[9] Abdullah Al-Qaqaa: Therapeutic Nutrition, Amman, Down Town, Al-Fuhais Commercial Complex, 2000

[10] Adel Turki: Principles of Athletic Training and Strength Training, Najaf, Dar Al-Diaa for Printing and Design, 2011.

[11] Muhammad Jasim Al-Yasiri and Akheran: The Analytical Statistics between Theory and Practice, 1st edition, Dar Al-Diaa for Printing, Najaf Al-Ashraf, 2011.

[12] Wadih Yassin and Hassan Muhammad Abdul-Ubaidi: Statistical Applications and Computer Uses in Physical Education Research, Mosul, Dar Al-Kutub for Printing and Publishing, 1999 AD.

[13] Alsayigh, H. A., \& Athab, N. A. (2016). The Study of Rectus Femoris Activity after Knee Joint Rehabilitation. International Journal of Pharm Tech Research, 9(9), 360-365.

[14] Athab, N. A., Hussein, W. R., \& Ali, A. A. M. (2019). A Comparative Study for Movement of Sword, Fencing, Stabbed, according to the Technical Programming in the Game of Fencing Wheelchairs Class B. Indian Journal of Public Health Research \& Development, 10(5), 1344-1347.

[15] Athab, N. A. (2019). An Analytical Study of Cervical Spine Pain According to the Mechanical Indicators of the Administrative Work Staff. Indian Journal of Public Health Research \& Development, 10(5), 1348-1354.

[16] Alsayigh, H. A., Athab, N. A., \& Firas, M. (2017). The Study of Electrical Activity of the Triceps Brachia Muscle according to the Chemical Changes of Water Loss during Spike in Volleyball. Journal of Global Pharma Technology, 57-62. 